\title{
Associations Between Variant Repeat Interruptions and Clinical Outcomes in Myotonic Dystrophy Type 1
}

Stephan Wenninger, MD, Sarah A. Cumming, PhD, Kristina Gutschmidt, MD, Kees Okkersen, MD, Aura Cecilia Jimenez-Moreno, PhD, Ferroudja Daidj, MSc, Hanns Lochmüller, MD, Fiona Hogarth, PhD, Hans Knoop, MD, Guillaume Bassez, MD, Darren G. Monckton, PhD, Baziel G.M. van Engelen, MD, and Benedikt Schoser, MD, on behalf of the OPTIMISTIC Consortium

Neurol Genet 2021;7:e572. doi:10.1212/NXG.0000000000000572

\author{
Correspondence \\ Dr. Wenninger \\ stephan.wenninger@ \\ med.uni-muenchen.de
}

\begin{abstract}
Objective

To assess the association between variant repeat (VR) interruptions in patients with myotonic dystrophy type 1 (DM1) and clinical symptoms and outcome measures after cognitive behavioral therapy $(\mathrm{CBT})$ intervention.
\end{abstract}

\section{Methods}

Adult patients with DM1 were recruited within the OPTIMISTIC trial (NCT02118779). Disease-related history, current clinical symptoms and comorbidities, functional assessments, and disease- and health-related questionnaires were obtained at baseline and after 5 and 10 months. After genetic analysis, we assessed the association between the presence of VR interruptions and clinical symptoms' long-term outcomes and compared the effects of CBT in patients with and without VR interruptions. Core trial outcome measures analyzed were: 6-minute walking test, DM1-Activ-C, Checklist Individual Strength Fatigue Score, Myotonic Dystrophy Health Index, McGill-Pain questionnaire, and Beck Depression inventory-fast screen. Blood samples for DNA testing were obtained at the baseline visit for determining CTG length and detection of VR interruptions.

\section{Results}

VR interruptions were detectable in $21 / 250$ patients (8.4\%) - 12 were assigned to the standard-of-care group (control group) and 9 to the CBT group. Patients with VR interruptions were significantly older when the first medical problem occurred and had a significantly shorter disease duration at baseline. We found a tendency toward a milder disease severity in patients with VR interruptions, especially in ventilation status, mobility, and cardiac symptoms. Changes in clinical outcome measures after CBT were not associated with the presence of VR interruptions.

\section{Conclusions}

The presence of VR interruptions is associated with a later onset of the disease and a milder phenotype. However, based on the OPTIMISTIC trial data, the presence of VR interruptions was not associated with significant changes on outcome measures after CBT intervention.

From the Department of Neurology (S.W., K.G., B.S.), Friedrich-Baur-Institute, Ludwig-Maximilians-Universität München, Germany; Institute of Molecular, Cell and Systems Biology (S.A.C., D.G.M.), University of Glasgow, United Kingdom; Department of Neurology (K.O., B.G.M.v.E.), Radboud University, Nijmegen, The Netherlands; Institute of Genetic Medicine (A.C.J.-M.), Institute for Ageing and Health, Newcastle University, United Kingdom; Neuromuscular Reference Centre (F.D., G.B.), Assistance Publique-Hôpitaux de Paris, France; Department of Neuropediatrics and Muscle Disorders (H.L.), University of Freiburg, Breisgau, Germany; Center for Genomic Regulation (H.L.), Barcelona Institute of Science and Technology, Spain; Tayside Clinical Trials Unit (F.H.), The University of Dundee, United Kingdom; and Department of Medical Psychology (H.K.), Amsterdam University Medical Centers, University of Amsterdam, Amsterdam Public Health Research Institute, Amsterdam, The Netherlands.

Go to Neurology.org/NG for full disclosures. Funding information is provided at the end of the article.

OPTIMISTIC Consortium coinvestigators are listed at appendix 2 at the end of the article.

The Article Processing Charge was funded by the authors.

This is an open access article distributed under the terms of the Creative Commons Attribution-NonCommercial-NoDerivatives License 4.0 (CC BY-NC-ND), which permits downloading and sharing the work provided it is properly cited. The work cannot be changed in any way or used commercially without permission from the journal. 


\section{Glossary}

6MWT = 6-minute walking test; BDI-Fs = Beck Depression inventory—fast screen; $\mathbf{C B T}=$ cognitive behavioral therapy; $\mathbf{C I S}=$ Checklist Individual Strength; DM1 = myotonic dystrophy type 1; ePAL = estimating the progenitor allele length; MDHI = Myotonic Dystrophy Health Index; PROM = patient-reported outcome measure; SAP = statistical analysis plan; VR = variant repeat.

\section{Trial Registration Information}

ClinicalTrials.gov NCT02118779.

Myotonic dystrophy type 1 (DM1) is an autosomal dominant inherited, clinically heterogeneous chronic progressive multisystem disorder caused by an expansion of a highly unstable CTG repeat in the DMPK gene. Overall, the age at onset and the severity of symptoms are linked to the number of inherited CTG repeats, ${ }^{1,2}$ as conventionally analyzed by Southern blot hybridization of restriction-digested genomic blood DNA. ${ }^{3}$ Using these methods, the phenotype-genotype correlation is rather weak and only explains the age at onset in approximately $20 \%-40 \%$ of the variation in age at onset. ${ }^{3-6}$ However, such measures of the average CTG repeat length fail to take account of the age-dependent somatic expansion observed in the blood $\mathrm{DNA}^{7-9}$ and estimating the inherited or progenitor allele length (ePAL, the lower boundary of the expanded allele distribution) using small-pool $\mathrm{PCR}^{8}$ has been shown to explain much more of the variability in age at onset $(\sim 70 \%))^{3}$ These data also revealed that the degree of somatic instability is an individual determinant of the age at onset in DM1. ${ }^{3}$ Furthermore, large cohort studies have shown that the presence of variant repeats (VRs) interrupting the DMPK CTG expansions reduces somatic instability and results in a later age at onset and delayed progression..$^{10-14}$ VRs have been identified in 3-11\% of patients with DM1 across various different ethnicities. ${ }^{10,14,15}$ VRs are located either at the $3^{\prime}$ or $5^{\prime}$ ends of DMPK expansions, and although CCG, CTC, GGC, and CAG interruptions have been identified, CCG VRs are, by far, the most common. ${ }^{10-12,15-18}$ In 2018, Cumming et al. ${ }^{19}$ described a later onset of the disease and a milder clinical phenotype in patients with DM1 with VRs in the OPTIMISTIC cohort.

As part of the OPTIMISTIC trial (NCT02118779 ${ }^{20}$ ), we performed an additional analysis on the association between the presence of VR interruptions and clinical symptoms, sociodemographic characteristics, and outcome measures after cognitive behavioral therapy (CBT) intervention. In the OPTIMISTIC study, we previously demonstrated that most outcome measures significantly improved after $\mathrm{CBT} .{ }^{21}$ In this trial, CBT was based on a previously constructed DM1 specific model of health status. Major determinants of health status in this model are: chronic fatigue, reduced initiative, and weak social interactions. Patients in the CBT group were assigned to a CBT-trained psychologist. After initial assessment of the main neuropsychological symptoms, an individual overall CBT goal was created by shared decision- making and using specific tools and modules (goal setting, getting started, sleep-wake pattern, activity, helpful beliefs, pain, and optimizing social interactions). Treatment sessions were conducted in person and by telephone on an individual frequency between baseline (V2) and month 10 (V4). ${ }^{21}$

\section{Methods}

\section{Protocol and Patient Population}

Data analyzed in this work were collected within the OPTIMISTIC trial, a multicenter study on the "Observational Prolonged Trial in Myotonic Dystrophy Type 1 to Improve Quality of Life-Standards, a Target Identification Collaboration.” The study purpose of the OPTIMISTIC trial, methods, patient selection and characteristics, and outcome measures were previously described. ${ }^{20,21}$ In summary, adult patients with DM1 aged older than or equal to 18 years with severe fatigue, based on a Checklist Individual Strength (CIS)-Fatigue score $\geq 35$ at the screening visit (V1), were enrolled in this 2 -arm, multicenter, randomized controlled study to evaluate the effectiveness of CBT on clinical outcome measures. The rationale for this longitudinal study is the model of perpetuating factors for fatigue in patients with DM1. ${ }^{22}$ For patients who were not able to provide historical genetic test results verifying a CTG repeat expansion at the screening visit, we performed an additional analysis after informed consent to provide the genetic test result for the presence of a CTG repeat expansion at the baseline visit (V2). In total, 255 patients consented to participate in this study and were enrolled at 4 different centers between April 2014 and May 2015 in the Netherlands, France, Germany, and the United Kingdom. At the baseline visit, the patients were assigned to either the control group or the intervention group 1:1, followed by 5-month (V3), 10-month (V4), and 16-month (V5) visits. CBT intervention was performed in patients assigned to the intervention group between V2 and V4. Disease-related history was obtained by historical medical reports and specific questionnaires filled out at screening or baseline visits by the patient and the investigator. At each visit, functional assessments, including muscular impairment rating scale and the 6-minute walking test (6MWT), were performed. In addition, disease- and health-related questionnaires (patient-reported outcome 
Table 1 Demographic Characteristics of Patients With (VR+) and Without Variant Repeats (VR-)

\begin{tabular}{|c|c|c|c|c|c|c|c|c|c|c|}
\hline & \multirow[b]{2}{*}{ Missing information } & \multicolumn{4}{|c|}{$\operatorname{VR}+(n=21[8.4 \%]) ; 13$ women $(61.9 \%)$} & \multicolumn{4}{|c|}{ VR- $(n=229[91.6 \%]) ; 103$ women $(45 \%)$} & \multirow[b]{2}{*}{$p$ Value } \\
\hline & & $\mathbf{n}$ & Mean & Median & SD & $\mathbf{n}$ & Mean & Median & SD & \\
\hline Age at first med. Problem & $25(10.0 \%)$ & 18 & 31.5 & 29.5 & 14.8 & 207 & 24.8 & 23.0 & 13.2 & 0.043 \\
\hline Age at diagnosis & $26(10.4 \%)$ & 19 & 33.4 & 30.0 & 15.5 & 205 & 37.1 & 36.0 & 12.9 & 0.248 \\
\hline Duration of the disease & $25(10.0 \%)$ & 18 & 13.6 & 11.8 & 8.2 & 207 & 20.7 & 20.4 & 10.3 & 0.035 \\
\hline Age at baseline visit & $0(0.0 \%)$ & 21 & 44.5 & 43.8 & 13.0 & 229 & 45.9 & 46.5 & 11.5 & 0.609 \\
\hline Inheritance & 96 (38.4\%) & 16 & \multicolumn{3}{|c|}{$6(37.5 \%)$ maternal } & 138 & \multicolumn{3}{|c|}{47 (34.1\%) maternal } & 0.164 \\
\hline
\end{tabular}

Data were normally distributed; group differences were assessed by a 2-sided $t$ test. Bold values indicate significant difference for $p \leq 0.05$.

measures, PROMs) were obtained, including the primary outcome measure DM1-Activ scale, reflecting as a tool to assess activity and participation in patients with DM1 and health status and cognitive-behavioral measures, as described previously. ${ }^{20,21}$ Although the OPTIMISTIC study covered a total of 16 questionnaires, 3 motor function assessments, and 2 cognitive tests, this analysis focused on 6 core outcome measures typically used in the clinical trials and applied in daily clinical practice. Blood samples for DNA testing were obtained at the baseline visit (V2) for determining CTG length by small-pool PCR, i.e., estimated progenitor CTG repeat length (ePAL), modal CTG repeat length, and the presence of VRs (VR+), using digestion with AciI. Patient's samples were shipped to the Newcastle

Figure 1 Age at Symptom Onset and at Baseline in Patients With Variant Repeats (VR+) and Without Variant Repeats (VR-)
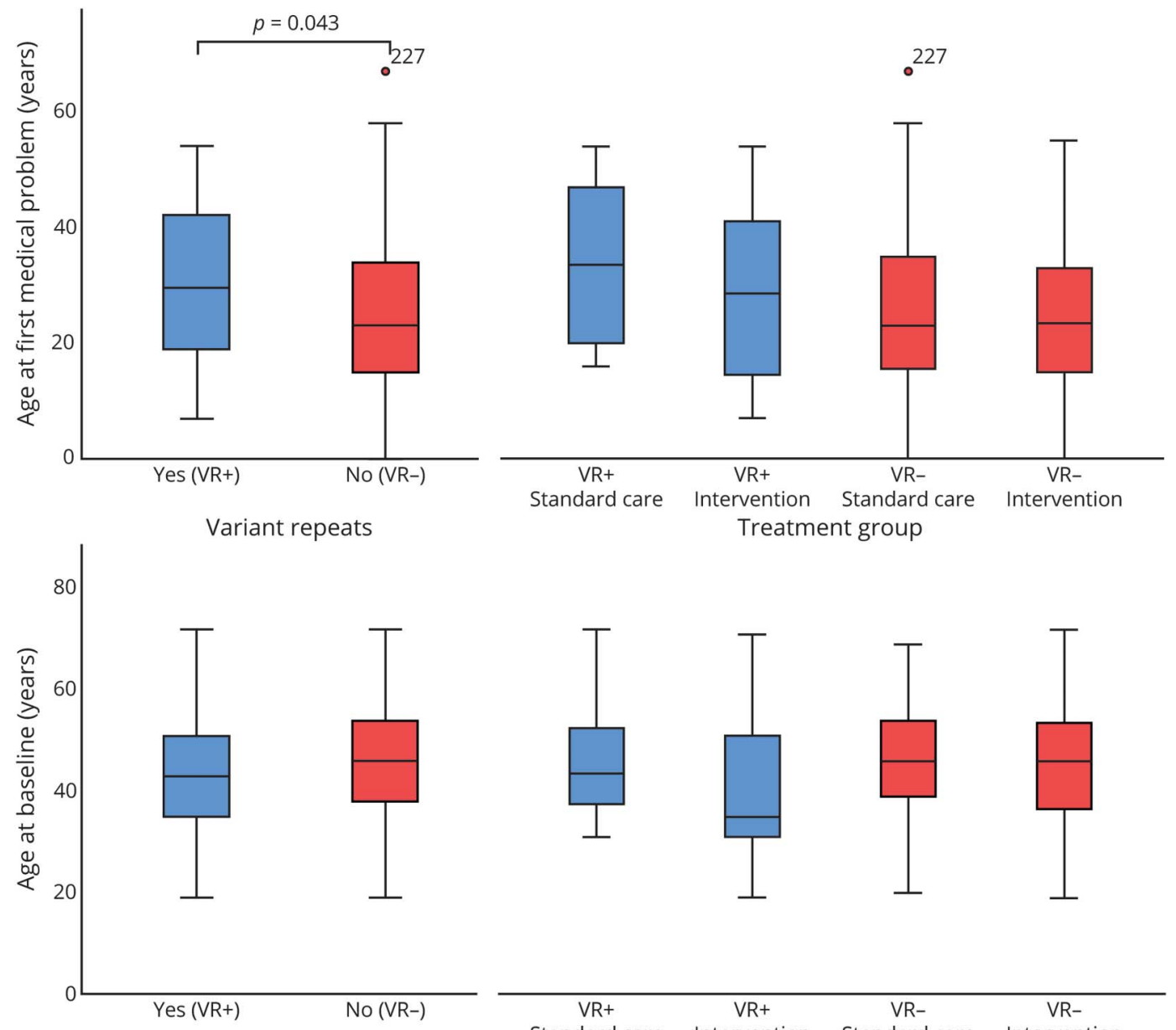

Treatment group
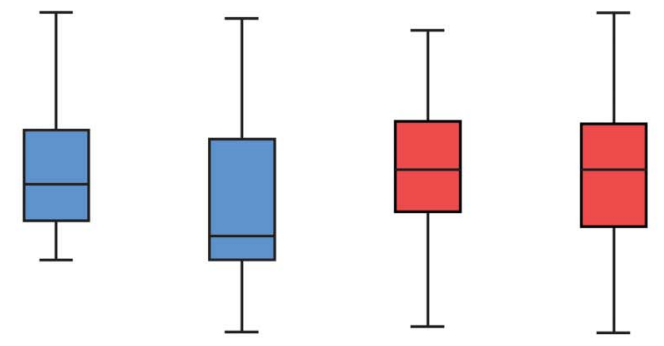

Variant repeats

\begin{tabular}{cccc}
\hline VR+ & VR+ & VR- & VR- \\
Standard care & Intervention & Standard care & Intervention \\
& Treatment group &
\end{tabular}


Table 2 Baseline Clinical Characteristics of the Study Cohort

\begin{tabular}{|c|c|c|}
\hline Baseline characteristics & $\operatorname{VR}+(n=21[8.4 \%]), n(\%)$ & VR- $(n=229[91.6 \%]), n(\%)$ \\
\hline BMI, median \pm SD & $25.4 \pm 4.4$ & $26.4 \pm 6.8$ \\
\hline \multicolumn{3}{|l|}{ MIRS } \\
\hline 1 & $1(4.8)$ & $7(3.1)$ \\
\hline 2 & $6(28.6)$ & $38(16.6)$ \\
\hline 3 & $9(42.9)$ & $82(35.8)$ \\
\hline 4 & $5(23.8)$ & $95(41.5)$ \\
\hline 5 & - & $7(3.1)$ \\
\hline \multicolumn{3}{|l|}{ Myotonia } \\
\hline Mild & $12(57.1)$ & $138(60.3)$ \\
\hline Severe & $5(23.8)$ & $59(25.8)$ \\
\hline Swallowing problems & $14(66.7)$ & $124(54.1)$ \\
\hline Cataracts & $6(28.6)$ & $75(32.8)$ \\
\hline \multicolumn{3}{|l|}{ Fatigue } \\
\hline Mild & $9(42.9)$ & $87(38.0)$ \\
\hline Severe & $12(57.1)$ & $128(55.9)$ \\
\hline Depression-not severe ${ }^{a}$ & $4(19.0)$ & $44(19.2)$ \\
\hline \multicolumn{3}{|l|}{ Ventilation } \\
\hline NIV part-time & $1(4.8)$ & $37(16.2)$ \\
\hline NIV full-time & - & - \\
\hline TIV & - & $1(0.4)$ \\
\hline \multicolumn{3}{|l|}{ Mobility (>1 yes possible) } \\
\hline Walk unaided & $20(95.2)$ & 183 (79.9) \\
\hline Walk with device & $1(4.8)$ & $46(20.1)$ \\
\hline Wheelchair use part-time & $2(9.5)$ & $35(15.3)$ \\
\hline \multicolumn{3}{|l|}{ Cardiac symptoms } \\
\hline Cardiomyopathy & $1(4.8)$ & $5(2.2)$ \\
\hline Arrhythmia/conduction block & $4(19.0)$ & $71(31.0)$ \\
\hline Not further specified & $2(9.5)$ & $6(2.6)$ \\
\hline Presence of pacemaker & $1(4.8)$ & $34(14.8)$ \\
\hline Presence of cardioverter/defibrillator & - & $7(3.1)$ \\
\hline Presence of any pacemaker, not specified & - & $5(2.2)$ \\
\hline
\end{tabular}

Abbreviations: $\mathrm{BMI}=$ body mass index; MIRS = muscular impairment rating scale; NIV = noninvasive ventilation; TIV = tracheostomy invasive ventilation; $\mathrm{VR}=$ variant repeat.

Data are presented as numbers and $\%$ of the subgroup.

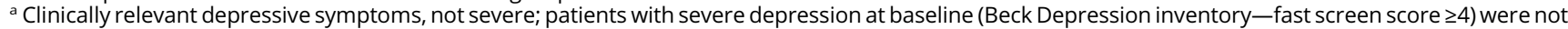
enrolled.

Research Biobank for Rare and Neuromuscular Diseases, and the genetic analysis was performed at the University of Glasgow. Detailed methods for detecting VRs are described in. ${ }^{19}$ Participants with missing data were excluded from relevant analyses.

\section{Standard Protocol Approvals, Registrations, and Patient Consents}

The study was approved by the institutional review boards at each of the 4 clinical sites (National Research Ethics Service Committee North East-Sunderland, UK, the Comite de 
Figure 2 Muscular Impairment Rating Scale (MIRS) at Baseline and Visit 4 in Patients With Variant Repeats (VR+) and Without Variant Repeats (VR-) in \% of the Subgroup

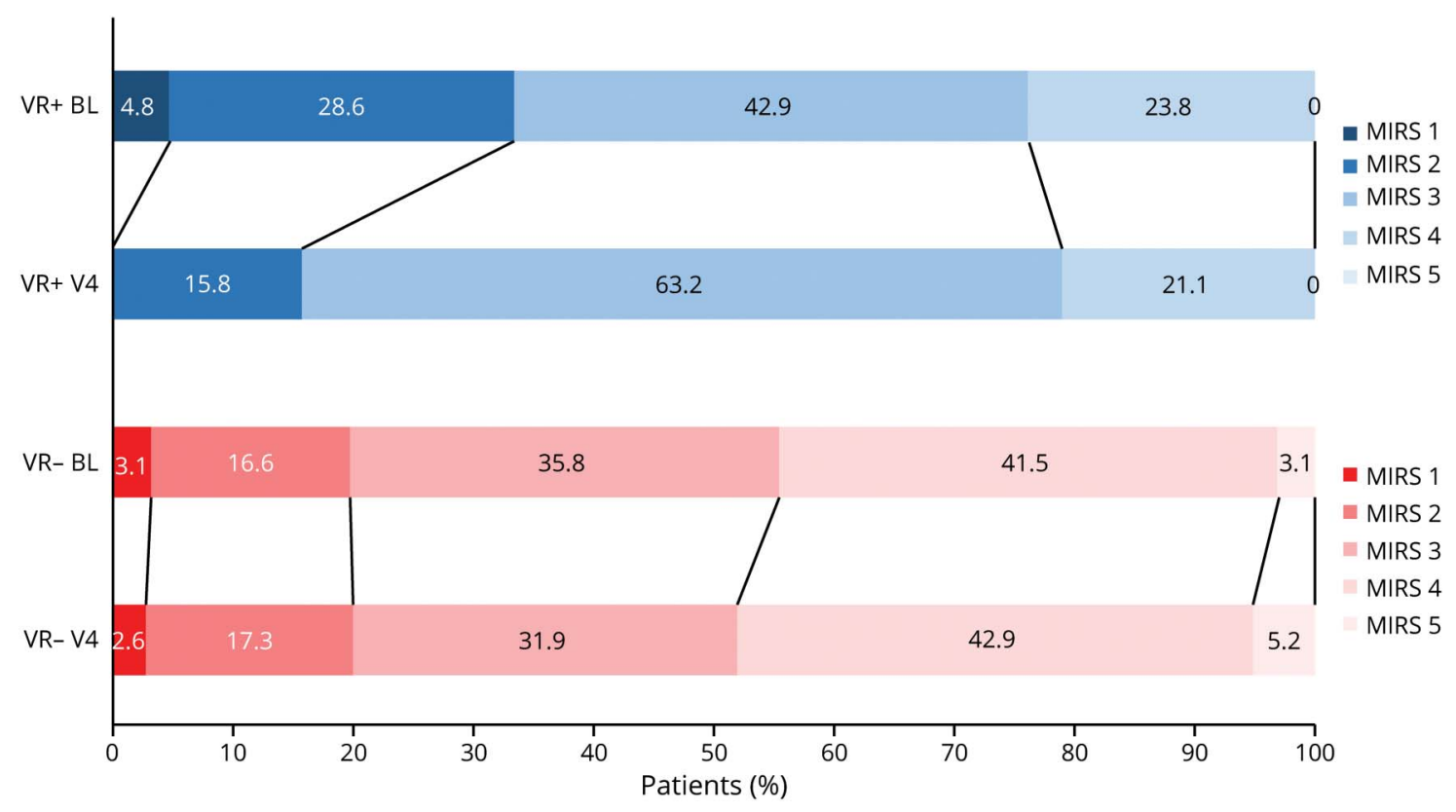

Protection des Personnes ile de France V, France, the Ethikkommission bei der LMU München, Germany, and the Concernstaf Kwaliteit en Veiligheid Commissie Mensgebonden Onderzoek Regio Arnhem-Nijmegen, the Netherlands). The protocol was registered on a public clinical trials registry (ClinicalTrials.gov, NCT02118779). All patients gave written informed consent to participate in this study. No photographs, videos, or other information with recognizable persons are published.

\section{Statistical Analysis}

In this additional analysis, we assessed the association between repeat interruptions and clinical symptoms, sociodemographic characteristics, and outcomes of CBT intervention in our OPTIMISTIC cohort. For this, we performed a subgroup analysis on patients with and without VRs (VR+/VR-) and their assignment to the intervention/control group. We ran descriptive and exploratory analysis, where applicable. We tested the data for normal distribution using Shapiro-Wilk tests. We used the 2-sided $t$ test, Pearson $\chi^{2}$ test, Mann-Whitey $U$ test, or Wilcoxon-rank-sum test, as appropriate. For statistical analysis, we used SPSS Statistics 25 and Microsoft Excel 2016. Significance level $(\alpha)$ was set at 0.05 . Because of the small number of patients with VRs and the clear imbalance of patient numbers across the subgroups, we focused on descriptive and group comparison analysis only.

\section{Data Availability}

The deidentified participant data are available on reasonable request from the study director Dr. Baziel G.M. van Engelen (baziel.vanengelen@radboudumc.nl). The study protocol and statistical analysis plan (SAP) are available online. ${ }^{20}$ The SAP was publicly available before completion of the study.

\section{Results}

\section{Variant Repeats}

Genetic data on VRs were available from 250 of 255 patients from the OPTIMISTIC cohort (98\%). VRs (VR+) were detectable in 21 of 250 patients (8.4\%), as described. ${ }^{19}$ Divided into subgroups, VRs were detectable in 12 patients in the standard-of-care group (control group) and 9 patients in the intervention group. The frequency of VRs in the whole cohort was $8.4 \%{ }^{19}$ and was similar in both the intervention $(7.03 \%)$ and the natural history groups $(9.83 \% ; p=0.425)$.

\section{Demographic and Clinical Baseline Characteristics}

Demographic and baseline characteristics are summarized in table 1. Patients with VRs were significantly older (mean 6.7 years) when the first medical problem occurred (table 1, figure $1, p=0.043)$. Furthermore, patients with VRs had a significantly shorter duration of the disease at baseline $(p=0.035)$. In about $2 / 3$ of patients, inheritance was paternal in both groups. The clinical baseline characteristics are summarized in table 2 . We found a tendency toward a milder disease severity in patients with VRs, especially in ventilation status, mobility, and cardiac symptoms (table 2, figure 2). Significantly less patients with VRs had any type of ventilation at baseline, underscoring the milder VR+ phenotype. Further analysis did not reveal any significant difference between the groups (e.g., VR+ treatment group vs VR- standard of care group).

\section{Medical History: First Symptoms}

First symptoms were primarily core muscular symptoms myotonia and muscle weakness in $2 / 3$ of the patients in both 
Table 3 First Symptoms Recalled by the Patients in Medical History

\begin{tabular}{|c|c|c|c|}
\hline & VR+ $(n=21[8.4 \%]) ; 13$ women $(61.9 \%)$ & VR- $(n=229$ [91.6\%]); 103 women $(45 \%)$ & \\
\hline & $\mathbf{N}(\%)$ & $\mathbf{N}(\%)$ & $p$ Value \\
\hline Muscle symptoms & $16(76.2)$ & $181(79.0)$ & 0.417 \\
\hline Muscle cramps/stiffness in hands & $10(47.6)$ & $110(48.0)$ & \\
\hline Muscle cramps/stiffness in jaw or tongue & $1(4.8)$ & - & \\
\hline Muscle pain & - & $10(4.4)$ & \\
\hline Muscle weakness & $4(19.0)$ & $48(21.0)$ & \\
\hline Swallowing problems & - & $3(1.3)$ & \\
\hline Dysarthria & $1(4.8)$ & $6(2.6)$ & \\
\hline Ptosis & - & $2(0.9)$ & \\
\hline Dyspnoea & - & $1(0.4)$ & \\
\hline Neuropsychological & $5(23.8)$ & $24(10.5)$ & 0.068 \\
\hline Cognitive problems & - & $1(0.4)$ & \\
\hline Daytime sleepiness & $4(19.0)$ & $17(7.4)$ & \\
\hline Fatigue & $1(4.8)$ & $6(2.6)$ & \\
\hline Cardiac symptoms & - & $4(1.7)$ & \\
\hline Gastrointestinal symptoms & - & $1(0.4)$ & \\
\hline Cataracts & - & $17(7.4)$ & \\
\hline Other & - & & n.a. \\
\hline Include: voice tone dropped, pain in knees & - & $2(0.9)$ & \\
\hline
\end{tabular}

Abbreviations: n.a. $=$ not applicable; $\mathrm{VR}=$ variant repeat. Group differences were calculated by Pearson $\chi^{2}$ tests.

groups (table 3). There were no significant differences between the 2 groups as to the nature of the first symptoms (i.e., neuromuscular vs neuropsychological).

\section{Association Between VR Interruptions and Intervention Outcomes}

We analyzed the association between VR interruptions and core outcome measures after CBT, which included the motor function assessment 6MWT and the PROMs DM1-Activ-C, the CIS, subscore fatigue, the Myotonic Dystrophy Health Index (MDHI), the McGill-Pain questionnaire, and the Beck Depression Inventory-fast screen (BDI-Fs). In patients with VRs (VR+), a significant change between baseline (V2) and after 10 months (V4) was only found in the CIS-Fatigue score. In the VR- group, significant changes between baseline and V4 were found for the 6MWT only in the intervention group and in the CIS-Fatigue score and MDHI score in both groups (table 4, figure 3). Effect size $r$ for significant differences between $\mathrm{V} 2$ and V4 was high $(>0.5)$ for CIS-fatigue in the VR+ CBT group $(r=$ $0.728)$, moderate $(0.3-0.5)$ for the CIS fatigue in the VRstandard care and intervention group, and low $(<0.3)$ for MDHI in the VR- standard care group and intervention group. Except for MDHI in the VR- standard-of-care group, the results of significant changes remained valid after Bonferroni correction for multiple testing and setting the significance level to $<0.008$. There was no significant difference in any outcome assessment between patients with and without VRs.

\section{Discussion}

This is the first analysis on the association between VR interruptions and core clinical symptoms, sociodemographic characteristics, and treatment effects of CBT in a large cohort of patients with myotonic dystrophy type 1 . This additional analysis was performed on data collected in the OPTIMISTIC trial. ${ }^{20,21}$ Of 255 patients enrolled, data on VR interruptions were available from 250 patients. The frequency of VRs in the whole cohort was $8.4 \%{ }^{19}$ and was similar in both the intervention and the natural history groups, which is within the rate of VR interruptions previously described in different cohorts. ${ }^{10,11,14}$ Overall, our additional analysis revealed that the presence of VRs resulted in a later onset of the disease and a tendency to a milder severity of the disease at baseline assessments, which is consistent with previous studies 
Table 4 Outcome Measures in the 4 Groups

\begin{tabular}{|c|c|c|c|c|c|c|c|c|c|c|}
\hline & \multirow[b]{3}{*}{$S^{*}$} & \multicolumn{9}{|c|}{ Standard care group $(n=122)$} \\
\hline & & \multicolumn{4}{|c|}{ VR- $(n=110)$} & \multicolumn{4}{|c|}{$V R+(n=12)$} & \multirow[b]{2}{*}{$\begin{array}{l}p \text { Value }{ }^{b} \text { VR+/VR- } \\
\text { group }\end{array}$} \\
\hline & & $\begin{array}{l}\text { Mean } \\
\text { V2 }\end{array}$ & $\begin{array}{l}\text { Mean } \\
\text { V4 }\end{array}$ & $\begin{array}{l}\text { Mean } \Delta, \\
\%\end{array}$ & $\begin{array}{l}p \text { Value }{ }^{\mathrm{a}} \text { change } \\
\text { V2/V4 }\end{array}$ & $\begin{array}{l}\text { Mean } \\
\text { V2 }\end{array}$ & $\begin{array}{l}\text { Mean } \\
\text { V4 }\end{array}$ & $\begin{array}{l}\text { Mean } \Delta, \\
\%\end{array}$ & $\begin{array}{l}p \text { Value }{ }^{a} \text { change } \\
\text { V2/V4 }\end{array}$ & \\
\hline 6MWT, m & $\mathrm{H}$ & 398.1 & 400.4 & 1 & 0.982 & 465.6 & 438.0 & -6 & 0.041 & 0.221 \\
\hline $\begin{array}{l}\text { DM1- } \\
\text { Activ-c }\end{array}$ & $\mathrm{H}$ & 61.9 & 60.4 & -2 & 0.306 & 73.8 & 67.3 & -10 & 0.221 & 0.291 \\
\hline $\begin{array}{l}\text { CIS- } \\
\text { fatigue }\end{array}$ & L & 45.2 & 40.4 & -12 & $<0.001 ; r=0.307$ & 42.8 & 43.0 & 0 & 0.833 & 0.058 \\
\hline MDHI & L & 36.8 & 33.0 & -12 & 0.010 & 30.8 & 31.0 & 1 & 0.575 & 0.886 \\
\hline $\begin{array}{l}\text { McGill- } \\
\text { pain }\end{array}$ & L & 30.9 & 28.7 & -8 & 0.828 & 29.8 & 35.3 & 16 & 0.514 & 0.597 \\
\hline \multirow[t]{4}{*}{ BDI-Fs } & L & 4.1 & 3.6 & -14 & 0.167 & 3.8 & 3.7 & -3 & 0.916 & 0.680 \\
\hline & & \multicolumn{9}{|c|}{ Intervention group $(n=128)$} \\
\hline & & \multicolumn{4}{|c|}{$V R-(n=119)$} & \multicolumn{4}{|c|}{$V R+(n=9)$} & \multirow[b]{2}{*}{$\begin{array}{l}p \text { Value }{ }^{\text {b }} \text { VR+/VR- } \\
\text { group }\end{array}$} \\
\hline & $S^{*}$ & $\begin{array}{l}\text { Mean } \\
\text { V2 }\end{array}$ & $\begin{array}{l}\text { Mean } \\
\text { V4 }\end{array}$ & $\begin{array}{l}\text { Mean } \Delta, \\
\%\end{array}$ & $\begin{array}{l}p \text { Value }^{\mathrm{a}} \text { change } \\
\text { V2/V4 }\end{array}$ & $\begin{array}{l}\text { Mean } \\
\text { V2 }\end{array}$ & $\begin{array}{l}\text { Mean } \\
\text { V4 }\end{array}$ & $\begin{array}{l}\text { Mean } \Delta, \\
\%\end{array}$ & $\begin{array}{l}p \text { Value }{ }^{a} \text { change } \\
\text { V2/V4 }\end{array}$ & \\
\hline 6MWT, m & $\mathrm{H}$ & 386.1 & 417.6 & 8 & $<0.001 ; r=0.119$ & 426.1 & 454.8 & 6 & 0.515 & 0.744 \\
\hline $\begin{array}{l}\text { DM1- } \\
\text { Activ-c }\end{array}$ & $\mathrm{H}$ & 61.1 & 63.8 & 4 & 0.241 & 62.2 & 65.1 & 4 & 0.373 & 0.535 \\
\hline $\begin{array}{l}\text { CIS- } \\
\text { fatigue }\end{array}$ & L & 45.0 & 36.9 & -22 & $<0.001 ; r=0.417$ & 44.0 & 29.3 & -50 & $0.008 ; r=0.728$ & 0.057 \\
\hline MDHI & L & 37.9 & 32.1 & -18 & $<0.001 ; r=0.153$ & 36.8 & 28.4 & -30 & 0.086 & 0.567 \\
\hline $\begin{array}{l}\text { McGill- } \\
\text { pain }\end{array}$ & L & 30.9 & 26.9 & -15 & 0.628 & 26.1 & 22.6 & -15 & 0.397 & 0.382 \\
\hline BDI-Fs & L & 4.2 & 4.1 & -2 & 0.311 & 6.0 & 4.0 & -50 & 0.127 & 0.187 \\
\hline
\end{tabular}

Abbreviations: $6 \mathrm{MWT}=6$-minute walking test; $\mathrm{BDI}-\mathrm{Fs}=$ Beck Depression inventory-fast screen score; CIS-fatigue = checklist individual strength score, subscore fatigue; McGill-pain = McGill-Pain Inventory fast screen score; MDHI = Myotonic Dystrophy Health Index score; $\mathrm{S}^{*}=$ score direction: $\mathrm{H}=$ higher values indicate improvement; $L=$ lower values indicate improvement; $V R=$ variant repeat.

All data were not normally distributed.

a Wilcoxon test was used for the comparison of outcomes at 2 time points.

${ }^{\mathrm{b}}$ Mann-Whitney test was used for the comparison of change (V2 to V4) in outcome measures between the VR+ and VR- groups. Bold values: significant difference for $p \leq 0.008$.

Effect size $r$ is provided for $p$ values $\leq 0.008$.

and our first analysis of the impact of VR interruptions on disease severity in patients with DM1. 3,11,12,14,19 However, the presence of VRs was not associated with significant changes in clinical outcome measures after CBT intervention. Although the limited power because of the small number of patients in the VR+ group has to be considered, our results may have a major influence on the interpretation of outcome measures in future clinical trials. Despite the later onset of symptoms in these patients, we did not identify significant differences in baseline characteristics, sociodemographic characteristics, or the occurrence of first symptoms. However, we could observe some tendencies toward a milder disease severity in patients with VRs, based on historic and current medical data on cardiac symptoms, mobility, and the use of assistive devices and ventilation status. Evaluating clinical symptoms and assessments at baseline relative to ePAL and age, patients with VRs tended to have, on average, a milder affected phenotype in several different domains. ${ }^{19}$ Subgroup analysis has to be interpreted with care because of the low number of patients with VRs. Where assessable, outcome measures showed an improvement in the 6MWT for patients with VRs in the standard-ofcare group with low effect size, but not in the intervention group. A significant change between baseline and 10-month visit after CBT was found for the CIS-fatigue in the intervention group both for VR+ and VR- patients but without a significant difference between the 2 subgroups. For CIS-fatigue, effect size was high in the VR+ intervention group $(r=0.728)$ and moderate in the VRintervention and in the standard-of-care group, respectively ( $r=$ 0.417 and $r=0.307$ ). For MDHI, a significant change was only detectable in patients without VRs both in the standard care and intervention groups with a low effect size.

One of the limitations of this analysis is the imbalance in patient numbers between subgroups, especially the low number of patients in the VR+ CBT group, so that group comparison analyses should be interpreted with care to avoid a statistical type II error. Because of the OPTIMISTIC protocol, a 
Figure 3 Core Outcome Measures for the 4 Subgroups for the 6MWT (A), DM1-Activ-c Score (B), Checklist Individual Strength, Subscore Fatigue (CIS-Fatigue) Score (C), and the Myotonic Dystrophy Health Index (MDHI) (D)
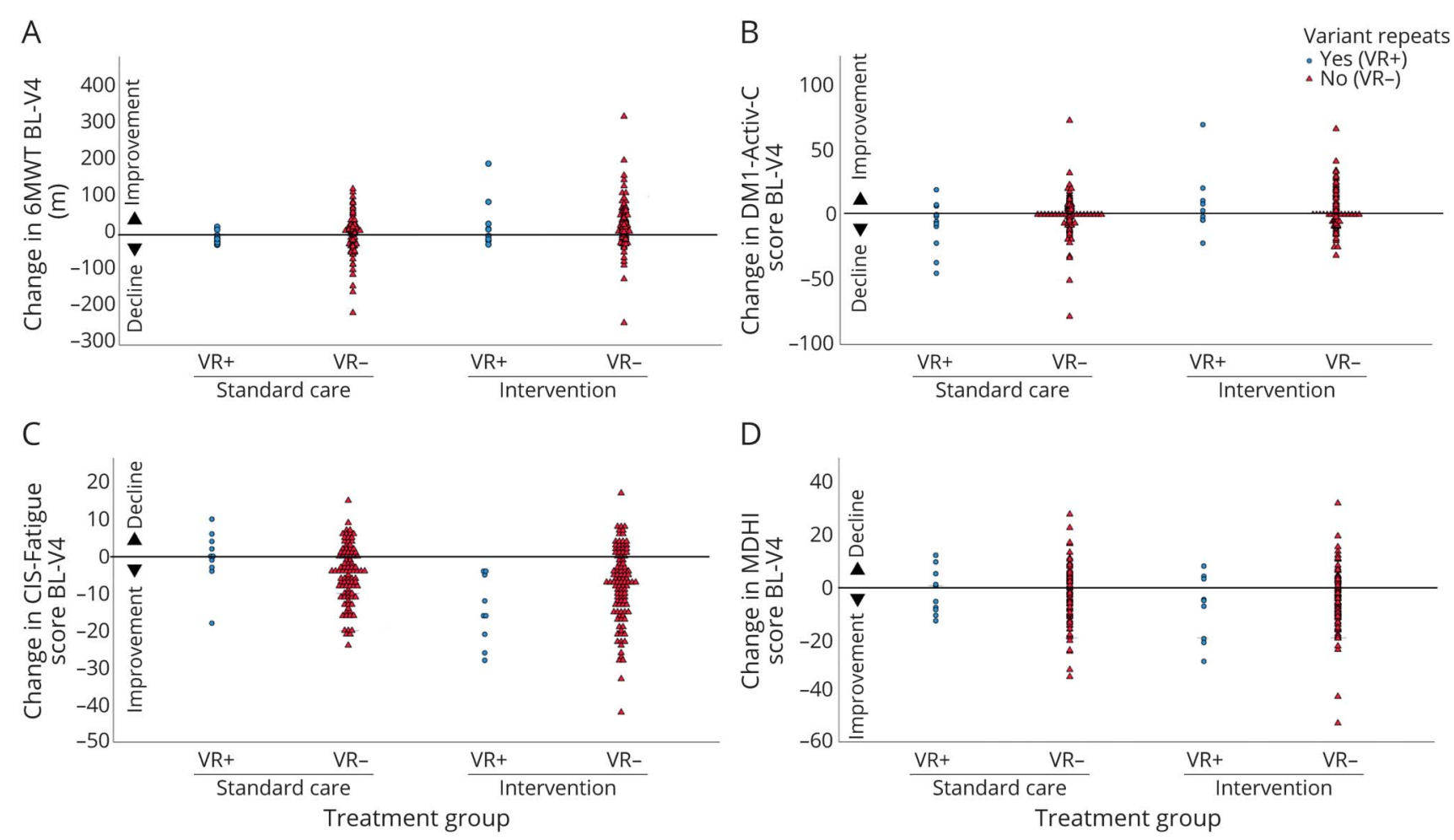

Higher values in 6MWT and DM1-Activ-c, and lower values in CIS-fatigue and MDHI indicate improvement. 6MWT = 6-minute walking test; DM1 = myotonic dystrophy type 1.

selection bias was predetermined because only patients with severe fatigue were enrolled (based on a CIS-fatigue score $\geq 35$ ). Furthermore, patients aged younger than 18 years and patients with severe depression at baseline (BDI-Fs score $\geq 4$ ) were not included in the study. ${ }^{20}$

In summary, based on data collected from this study cohort, the presence of VRs has no detectable effect on outcomes after CBT treatment. However, according to our data, the presence of VRs suggests a later onset of the disease and is associated with a milder phenotype. To date, it remains unclear whether the presence of VR interruptions in the DMPK gene is associated with improvement of clinical symptoms after investigational therapy. Further studies will investigate the effects of VR interruptions, in which case the percentage of VR+ and VR-patients should be balanced between the intervention and control arms of the trial.

\section{Acknowledgment}

The authors thank the participants and their family members of the OPTIMISTIC cohort and Mojgan Reza and staff at the Newcastle Research Biobank for Rare and Neuromuscular Diseases for preparing and shipping the OPTIMISTIC DNA samples, Shaun Treweek (University of Aberdeen) for trial design and implementation, and the Tayside Clinical Trials Unit for collation and provision of participant data.

\section{Study Funding}

This study was funded by the European Union Seventh Framework Program, under grant agreement no. 305697 (the Observational Prolonged Trial In Myotonic dystrophy type 1 to Improve Quality of Life Standards, a Target Identification Collaboration [OPTIMISTIC] project) and research fund by the Deutsche Gesellschaft für Muskelkranke e.V. group Germany. D.G. Monckton has been supported by donations from the Myotonic Dystrophy Support Group. S. Wenninger has received research fund by the DGM-Deutsche Gesellschaft für Muskelkranke e.V.

\section{Disclosure}

S. Wenninger has served on advisory boards for Alexion Pharma, CSL Behring, and Sanofi Genzyme GmbH and received funding for travel or speaker honoraria from SanofiAventis GmbH, SH Glykogenose Gesellschaft Germany, AbbVie GmbH, Recordati Pharma GmbH, CSL-Behring $\mathrm{GmbH}$, Alexion Pharma Germany GmbH, Desitin, and Akcea GmbH. S.A. Cumming, K. Gutschmidt, K. Okkersen, A.C. Jimenez-Moreno, H. Knoop, and F. Daidj have nothing to report. H. Lochmüller reports consultancy and financial support for research projects and clinical trials from Amplo Biotechnology, AMO Pharma, Biogen, Desitin, Fulcrum Therapeutics, GW Pharma, Milo Biotechnology, Pfizer, PTC Therapeutics, Roche, Santhera, Sarepta, Satellos, and 
Ultragenyx and is editor-in-chief for the Journal of Neuromuscular Disease (IOS Press). F. Hogarth has nothing to report. G. Bassez reports grants from AFM-Telethon, personal fees and other from Lupin Pharmaceuticals, nonfinancial support and other from the Myotonic Dystrophy Foundation, and nonfinancial support from AMO Pharma, outside the submitted work. D.G. Monckton has been a scientific consultant and/or received an honoraria/stock options from AMO Pharma, Biogen Idec, Charles River, LoQus23, Small Molecule RNA, Triplet Therapeutics and Vertex Pharmaceuticals and had research contracts with AMO Pharma and Vertex Pharmaceuticals; has received research grants/contracts from the European Union, CHDI, European Huntington Disease Network, Huntington Disease Society of America, National Institute of Health, Muscular Dystrophy UK and the Myotonic Dystrophy Support Group; and is on the Scientific Advisory Board of Myotonic (formerly the Myotonic Dystrophy Foundation) and EuroDyMA (European Dystrophia Myotonica Association), is a scientific advisor to the Myotonic Dystrophy Support Group and is a vice president of Muscular Dystrophy UK. B.G.M. van Engelen reports grants from Marigold Canada, outside the submitted work. B. Schoser is a member of the Neuromuscular advisory board of Audentes Therapeutics, Nexien biotherapeutics, and Dyne; he received speaker honoraria from Sanofi Genzyme, Amicus Therapeutics, Lupin Pharmaceuticals, during the past 3 years; he received unrestricted research grants from Sanofi Genzyme, Amicus therapeutics, and Greenovation. Go to Neurology. org/NG for full disclosures.

\section{Publication History}

Received by Neurology: Genetics September 23, 2020. Accepted in final form February 4, 2021.

Appendix 1 Authors

\begin{tabular}{|c|c|c|}
\hline Name & Location & Contribution \\
\hline $\begin{array}{l}\text { Stephan } \\
\text { Wenninger, } \\
\text { MD }\end{array}$ & $\begin{array}{l}\text { Friedrich-Baur-Institute, } \\
\text { Ludwig-Maximilians- } \\
\text { University of Munich, } \\
\text { Germany }\end{array}$ & $\begin{array}{l}\text { Patient acquisition and } \\
\text { examination, acquisition } \\
\text { of data, statistical analysis } \\
\text { and interpretation of data, } \\
\text { first manuscript draft, } \\
\text { critical revision of the } \\
\text { manuscript for intellectual } \\
\text { content, and final } \\
\text { manuscript draft }\end{array}$ \\
\hline
\end{tabular}

\begin{tabular}{lll}
\hline $\begin{array}{l}\text { Sarah A. } \\
\text { Cumming, } \\
\text { PhD }\end{array}$ & $\begin{array}{l}\text { Institute of Molecular, Cell } \\
\text { and Systems Biology, } \\
\text { College of Medical, } \\
\text { Veterinary and Life } \\
\text { Sciences, University of } \\
\text { Glasgow, United Kingdom }\end{array}$ & $\begin{array}{l}\text { Major role in acquisition of } \\
\text { genetic data, analysis and } \\
\text { interpretation of data, and } \\
\text { critical revision of the } \\
\text { manuscript for intellectual } \\
\text { content }\end{array}$ \\
\hline $\begin{array}{l}\text { Kristina } \\
\text { Gutschmidt, } \\
\text { MD }\end{array}$ & $\begin{array}{l}\text { Friedrich-Baur-Institute, } \\
\text { Ludwig-Maximilians- } \\
\text { University of Munich, } \\
\text { Germany }\end{array}$ & $\begin{array}{l}\text { Acquisition of clinical data } \\
\text { and critical revision of the } \\
\text { manuscript for intellectual } \\
\text { content }\end{array}$ \\
& &
\end{tabular}

Appendix 1 (continued)

\begin{tabular}{lll}
\hline Name & Location & Contribution \\
\hline $\begin{array}{l}\text { Kees } \\
\text { Okkersen, }\end{array}$ & $\begin{array}{l}\text { Radboud University } \\
\text { Medical Center, Donders } \\
\text { Institute of Brain, Imaging } \\
\text { and Cognition, Nijmegen, } \\
\text { The Netherlands }\end{array}$ & $\begin{array}{l}\text { Major role in recruitment of } \\
\text { participants and acquisition } \\
\text { of biological samples and } \\
\text { clinical data and critical } \\
\text { revision of the manuscript } \\
\text { for intellectual content }\end{array}$ \\
\end{tabular}

\begin{tabular}{lll}
\hline Aura Cecilia & University of Newcastle, & Major role in recruitment of \\
Jimenez- & United Kingdom & $\begin{array}{l}\text { participants and acquisition } \\
\text { of biological samples and } \\
\text { Moreno, PhD }\end{array}$ \\
& & $\begin{array}{l}\text { clinical data and critical } \\
\text { revision of the manuscript } \\
\text { for intellectual content }\end{array}$ \\
\end{tabular}

Ferroudja Neuromuscular Reference Major role in recruitment of

Daidj, MSc Centre, Pitié-Salpêtrière participants and acquisition Hospital, Assistance of biological samples and Publique-Hôpitaux de clinical data and critical Paris, France revision of the manuscript for intellectual content

\begin{tabular}{|c|c|c|}
\hline $\begin{array}{l}\text { Hanns } \\
\text { Lochmüller, } \\
\text { MD }\end{array}$ & $\begin{array}{l}\text { Children's Hospital of } \\
\text { Eastern Ontario Research } \\
\text { Institute; Division of } \\
\text { Neurology, Department of } \\
\text { Medicine, The Ottawa } \\
\text { Hospital; and Brain and } \\
\text { Mind Research Institute, } \\
\text { University of Ottawa, } \\
\text { Ontario, Canada }\end{array}$ & $\begin{array}{l}\text { Coordination of DNA } \\
\text { sample collection, clinical } \\
\text { study design, and critical } \\
\text { revision of the manuscript } \\
\text { for intellectual content }\end{array}$ \\
\hline
\end{tabular}

\begin{tabular}{|c|c|c|}
\hline $\begin{array}{l}\text { Fiona } \\
\text { Hogarth, } \\
\text { PhD }\end{array}$ & $\begin{array}{l}\text { Tayside Clinical Trials Unit, } \\
\text { University of Dundee, } \\
\text { United Kingdom }\end{array}$ & $\begin{array}{l}\text { Major role in acquisition of } \\
\text { clinical data, discussion of } \\
\text { results, and critical revision } \\
\text { of the manuscript for } \\
\text { intellectual content }\end{array}$ \\
\hline $\begin{array}{l}\text { Hans Knoop, } \\
\text { MD }\end{array}$ & $\begin{array}{l}\text { Medical Psychology of the } \\
\text { Amsterdam University } \\
\text { Medical Centers, } \\
\text { University of Amsterdam, } \\
\text { The Netherlands }\end{array}$ & $\begin{array}{l}\text { Supervision of } \\
\text { recruitment, data and } \\
\text { sample acquisition and } \\
\text { clinical study design, and } \\
\text { critical revision of the } \\
\text { manuscript for intellectual } \\
\text { content }\end{array}$ \\
\hline $\begin{array}{l}\text { Guillaume } \\
\text { Bassez, MD }\end{array}$ & $\begin{array}{l}\text { Neuromuscular Reference } \\
\text { Centre, Pitié-Salpêtrière } \\
\text { Hospital, Assistance } \\
\text { Publique-Hôpitaux de } \\
\text { Paris, France }\end{array}$ & $\begin{array}{l}\text { Supervision of } \\
\text { recruitment, data and } \\
\text { sample acquisition and } \\
\text { clinical study design, and } \\
\text { critical revision of the } \\
\text { manuscript for intellectual } \\
\text { content }\end{array}$ \\
\hline
\end{tabular}

Darren G. Institute of Molecular, Cell Genetic study concept and Monckton, and Systems Biology, design, study supervision, PhD College of Medical, data analysis, and critical Veterinary and Life revision of the manuscript Sciences, University of for intellectual content Glasgow, United Kingdom

\begin{tabular}{lll}
\hline $\begin{array}{l}\text { Baziel G.M. } \\
\text { van Engelen, } \\
\text { MD }\end{array}$ & $\begin{array}{l}\text { Department of Neurology, } \\
\text { Donders Institute for Brain } \\
\text { Cognition and Behaviour, } \\
\text { Radboud University } \\
\text { Medical Centre, Nijmegen, } \\
\text { The Netherlands }\end{array}$ & $\begin{array}{l}\text { Supervision of } \\
\text { recruitment, data and } \\
\text { sample acquisition, and } \\
\text { the overall study, clinical } \\
\text { study design, and critical } \\
\text { revision of the manuscript } \\
\text { for intellectual content }\end{array}$ \\
\hline $\begin{array}{l}\text { Benedikt } \\
\text { Schoser, MD }\end{array}$ & $\begin{array}{l}\text { Friedrich-Baur-Institute, } \\
\text { Ludwig-Maximilians- } \\
\text { University of Munich, } \\
\text { Germany }\end{array}$ & $\begin{array}{l}\text { Supervision of } \\
\text { recruitment, data and } \\
\text { sample acquisition and } \\
\text { clinical study design, and } \\
\text { critical revision of the } \\
\text { manuscript for intellectual } \\
\text { content }\end{array}$ \\
& &
\end{tabular}




\section{Appendix 2. Coinvestigators}

Coinvestigators are listed at links.Iww.com/NXG/A398.

\section{References}

1. Harley HG, Brook JD, Rundle SA, et al. Expansion of an unstable DNA region and phenotypic variation in myotonic dystrophy. Nature 1992;355:545-546.

2. Harley HG, Rundle SA, MacMillan JC, et al. Size of the unstable CTG repeat sequence in relation to phenotype and parental transmission in myotonic dystrophy. Am J Hum Genet 1993;52:1164-1174.

3. Morales F, Couto JM, Higham CF, et al. Somatic instability of the expanded CTG triplet repeat in myotonic dystrophy type 1 is a heritable quantitative trait and modifier of disease severity. Hum Mol Genet 2012;21:3558-3567.

4. Marchini C, Lonigro R, Verriello L, Pellizzari L, Bergonzi P, Damante G. Correlations between individual clinical manifestations and CTG repeat amplification in myotonic dystrophy. Clin Genet 2000;57:74-82.

5. Mladenovic J, Pekmezovic T, Todorovic S, et al. Survival and mortality of myotonic dystrophy type 1 (Steinert's disease) in the population of Belgrade. Eur J Neurol 2006;13:451-454.

6. Perini GI, Menegazzo E, Ermani M, et al. Cognitive impairment and (CTG)n expansion in myotonic dystrophy patients. Biol Psychiatry 1999;46:425-431.

7. Martorell L, Monckton DG, Gamez J, et al. Progression of somatic CTG repeat length heterogeneity in the blood cells of myotonic dystrophy patients. Hum Mol Genet 1998; $7: 307-312$.

8. Monckton DG, Wong LJ, Ashizawa T, Caskey CT. Somatic mosaicism, germline expansions, germline reversions and intergenerational reductions in myotonic dystrophy males: small pool PCR analyses. Hum Mol Genet 1995;4:1-8.

9. Wong LJ, Ashizawa T, Monckton DG, Caskey CT, Richards CS. Somatic heterogeneity of the CTG repeat in myotonic dystrophy is age and size dependent. Am J Hum Genet 1995;56:114-122.

10. Braida C, Stefanatos RK, Adam B, et al. Variant CCG and GGC repeats within the CTG expansion dramatically modify mutational dynamics and likely contribute toward unusual symptoms in some myotonic dystrophy type 1 patients. Hum Mol Genet 2010;19:1399-1412.
11. Pesovic J, Peric S, Brkusanin M, Brajuskovic G, Rakocevic-Stojanovic V, Savic-Pavicevic D. Repeat interruptions modify age at onset in myotonic dystrophy type 1 by stabilizing DMPK expansions in somatic cells. Front Genet 2018;9:601.

12. Cumming SA, Hamilton MJ, Robb Y, et al. De novo repeat interruptions are associated with reduced somatic instability and mild or absent clinical features in myotonic dystrophy type 1. Eur J Hum Genet 2018;26:1635-1647.

13. Overend G, Legare C, Mathieu J, Bouchard L, Gagnon C, Monckton DG. Allele length of the DMPK CTG repeat is a predictor of progressive myotonic dystrophy type 1 phenotypes. Hum Mol Genet 2019;28:2245-2254.

14. Miller JN, van der Plas E, Hamilton M, et al. Variant repeats within the DMPK CTG expansion protect function in myotonic dystrophy type 1. Neurol Genet 2020;6:e504

15. Musova Z, Mazanec R, Krepelova A, et al. Highly unstable sequence interruptions of the CTG repeat in the myotonic dystrophy gene. Am J Med Genet A 2009;149A: 1365-1374.

16. Santoro M, Masciullo M, Silvestri G, Novelli G, Botta A. Myotonic dystrophy type 1 role of CCG, CTC and CGG interruptions within DMPK alleles in the pathogenesis and molecular diagnosis. Clin Genet 2017;92:355-364.

17. Botta A, Rossi G, Marcaurelio M, et al. Identification and characterization of 5' CCG interruptions in complex DMPK expanded alleles. Eur J Hum Genet 2017;25: 257-261.

18. Tome S, Dandelot E, Dogan C, et al. Unusual association of a unique CAG interruption in 5' of DM1 CTG repeats with intergenerational contractions and low somatic mosaicism. Hum Mutat 2018;39:970-982.

19. Cumming SA, Jimenez-Moreno C, Okkersen K, et al. Genetic determinants of disease severity in the myotonic dystrophy type 1 OPTIMISTIC cohort. Neurology 2019;93: e995-e1009.

20. van Engelen B, Consortium O, Abghari S, et al. Cognitive behaviour therapy plus aerobic exercise training to increase activity in patients with myotonic dystrophy type 1 (DM1) compared to usual care (OPTIMISTIC): study protocol for randomised controlled trial. Trials 2015;16:224.

21. Okkersen K, Jimenez-Moreno C, Wenninger S, et al. Cognitive behavioural therapy with optional graded exercise therapy in patients with severe fatigue with myotonic dystrophy type 1: a multicentre, single-blind, randomised trial. Lancet Neurol 2018; 17:671-680.

22. Kalkman JS, Schillings ML, Zwarts MJ, van Engelen BG, Bleijenberg G. The development of a model of fatigue in neuromuscular disorders: a longitudinal study. J Psychosom Res 2007;62:571-579. 


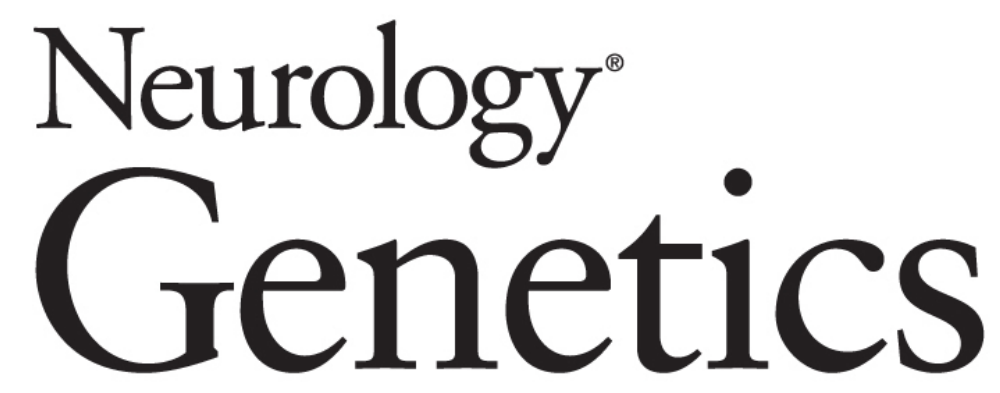

\section{Associations Between Variant Repeat Interruptions and Clinical Outcomes in Myotonic Dystrophy Type 1 \\ Stephan Wenninger, Sarah A. Cumming, Kristina Gutschmidt, et al. Neurol Genet 2021;7; \\ DOI 10.1212/NXG.0000000000000572}

This information is current as of March 9, 2021

Neurol Genet is an official journal of the American Academy of Neurology. Published since April 2015, it is an open-access, online-only, continuous publication journal. Copyright Copyright $\odot 2021$ The Author(s). Published by Wolters Kluwer Health, Inc. on behalf of the American Academy of Neurology.. All rights reserved. Online ISSN: 2376-7839.

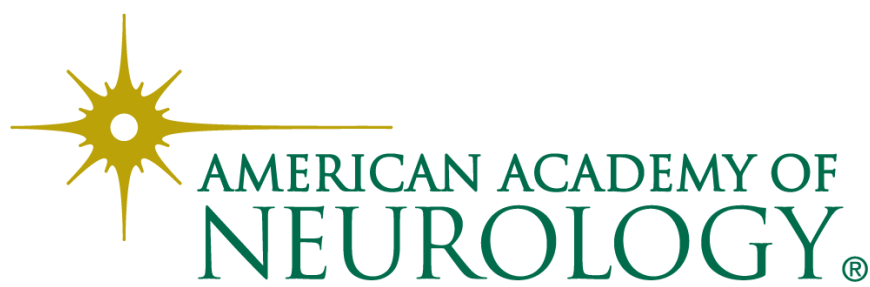




\section{Updated Information \& Services}

References

Citations

Subspecialty Collections

Permissions \& Licensing

Reprints including high resolution figures, can be found at: http://ng.neurology.org/content/7/2/e572.full.html

This article cites 22 articles, 1 of which you can access for free at: http://ng.neurology.org/content/7/2/e572.full.html\#\#ref-list-1

This article has been cited by 1 HighWire-hosted articles: http://ng.neurology.org/content/7/2/e572.full.html\#\#otherarticles

This article, along with others on similar topics, appears in the following collection(s):

All Neuropsychology/Behavior

http://ng.neurology.org//cgi/collection/all_neuropsychology_behavior Clinical trials Randomized controlled (CONSORT agreement)

http://ng.neurology.org//cgi/collection/clinical_trials_randomized_cont rolled_consort_agreement

Muscle disease

http://ng.neurology.org//cgi/collection/muscle_disease

Information about reproducing this article in parts (figures,tables) or in its entirety can be found online at:

http://ng.neurology.org/misc/about.xhtml\#permissions

Information about ordering reprints can be found online:

http://ng.neurology.org/misc/addir.xhtml\#reprintsus

Neurol Genet is an official journal of the American Academy of Neurology. Published since April 2015, it is an open-access, online-only, continuous publication journal. Copyright Copyright $\odot 2021$ The Author(s). Published by Wolters Kluwer Health, Inc. on behalf of the American Academy of Neurology.. All rights reserved. Online ISSN: 2376-7839.

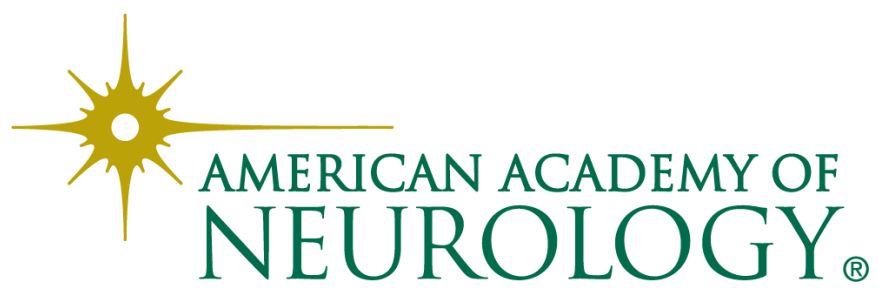

